\title{
Effect of Solarization with Different Thickness of Polyethylene and Organic Fertilizer on Canola (Brassica Napus L.) Yield and Yield Components, Weeds, Soil and Fungi Densities
}

\author{
Abdullatif A. Neamatallah \\ Environment Department, Faculty of Meteorology, \\ Environment and Arid Land Agriculture, \\ King Abdulaziz University, Jeddah, \\ Saudi Arabia
}

\begin{abstract}
The present research work studied the effects of soil solarization with different thicknesses of polyethylene films $100 \mu, 250 \mu, 500 \mu$ amended with soil covering with mixtures of plant residues (Cabbage and Canola), and (municipal wastewater sludge + chicken manure, municipal wastewater sludge + sheep manure and municipal wastewater sludge + cow manure) on canola (Brassica napus L.) growth parameters and seed protein and oil content. The study was carried out during 2015/2016 and 2016/2017 seasons in Hada Al-Sham Agricultural Research Station of King Abdulaziz University. The results of the study showed that covering the soil with transparent polyethylene thickness of $\mathbf{1 0 0}$ microns increased canola growth components and increased seed protein and oil content compared to the other polyethylene thicknesses, and also chicken manure positively improved and enhanced all these canola plant growth parameters and its seed protein and oil content compared with other organic fertilizers. Generally, soil solarization amended with or without plant residues or organic manures improved and increased canola plat growth parameters and its seed quality.
\end{abstract}

Key words: Canola, solarization, organic fertilizers, plant residue.

\section{INTRODUCTION}

Soil solarization is used all over the world as means and method for controlling weed growth and adjusting soil conditions for best crop and vegetable productions. It aids solar heating of the soil due to covering with transparent polyethylene sheets. This leads to killing and eradication of the soil borne pests (Katan et al., 2000). Soil solarization is a method used for eradication of wide range of soil-borne pathogens, nematodes, and weed seed and seedlings as a result the high soil temperature initiated by covering of soil with transparent polyethylene sheets. Due to solarization also soil structure improves and soil content of soluble nutrients, dissolved organic matter, and inorganic nitrogen forms increase, and cations become more available (Addabbo et al., 201). Katan 1987; Stapleton and DeVay 1995; Stapleton, 2000 found an increase in concentration of soluble mineral nutrients in solarized soil which might have been due to the death and degradation of soil microbiota killed by the heat treatment. Fertilizing rice with chicken manure attained the highest grain yields under lowland conditions compared to farm wastes and green manures, (Budhar et al., 1991) indicating the superiority of poultry manure. Composted chicken manure (CCM) gave the highest potato yield compared to FYM in India, which was due to higher availability of soil nutrients and uptake by the crop enhanced by chicken manure (Amanullah et al., 2007c). Chicken manure fertilization at rate of $20 \mathrm{t}$ ha1 (Zamil et al., 2004). Okra plants total carbohydrate, protein and ascorbic acid increased and crude fiber content decreased under application of $+50 \mathrm{~kg} \mathrm{~N}$ as chicken manure (Saleha, 1992). Solarization increases both temperature and soil moisture which in their turn influence the rate of mineralization of soil organic matter, (Akhtar and Malik, 2000; Thuriès et al., 2000; Gelsomino et al., 2006), and ultimately enhancing plant growth (Chen et al., 2000). On the other hand, Assaf et al. 2006 said that long-term use of solarization supplemented with high doses of organic matter will have negative effects on both plant growth and beneficial soil biota populations, and (Gamliel et al., 2000) mentioned that plant growth under soil solarization can be reduced if the crop is planted before the organic material has been fully degraded. The aim of this study is to investigate the effect of polyethylene mulching (solarization), amended with plant residues and organic fertilizers on canola growth parameters and its seeds qualities under arid land conditions.

\section{MATERIALS AND METHODS}

\section{Experimental Design}

The design in this experiment is split split plot design with 4 replications. The transparent polyethylene film thicknesses (100, 250 and 500 micrometer and control without any cover) represented the main plots, and Cabbage and Canola plant residues represented the sub plots, while the combinations of the municipal wastewater sludge with the animal manures (MMW) (sludge + chicken manure, sludge + sheep manure and sludge + cow manure) is representing the sub-sub plot treatments. The plot size is 2 X $3.2 \mathrm{~m}$. Soil solarization was achieved during the period of 1st July to 31th August. The experimental field was tilled using moldboard plow then harrowed with the disk harrows, and leveled. 
Preparation of seedlings and planting of canola:

Canola (Brassica napus L.) Pactool cultivar seedlings were prepared in the nursery and seedlings were sawn in the field in 15 and 20 November in the 1st and 2nd seasons, respectively.

\section{Fertilizer Application}

After solarization the land was fertilized with $500 \mathrm{~kg} / \mathrm{ha} 20$ 20-20 (N-P-K) applied at four equal doses in 15 days intervals during the growth period. Seedlings were planted in rows $40 \mathrm{~cm}$ between each 2 rows and $20 \mathrm{~cm}$ between each 2 row hills.

\section{Irrigation}

The drip irrigation system was applied for irrigation of the cultivated crop, where a program of irrigation scheduling based on crop water requirements was followed after plant transplantation. The field experiment was irrigated till saturation before planting canola seedlings.

\section{Collection of data}

Plant height, spike length, and number of grains per spike were recorded from ten randomly selected plants from each plot. Total number of spikes was measured in $1 \mathrm{~m} 2$ in each plot.

Protein content (\%) was measured using Kjeltec Auto 1030 Analyzer after treated with sulfuric acid and protein content was calculated according the following equation protein $\%=$ N\% * 6.25 according to A.O.A.C. (2000).

\section{Statistical Analysis}

Data of canola growth components and seed protein and oil content was statistically analyzed using analysis of variance based to El-Nakhlawy (2010) applying SAS program (2006), and means were determined using LSD test according to El-

Nakhlawy (2010).

\section{RESULTS AND DISCUSSION}

Analysis of variance and mean comparisons of the studied traits.

Canola Traits

Analysis of variance

The results of the effects of solarization amended with plant residue, organic fertilizers and their interactions are presented:

\section{Plant height:}

The mean square significance test showed that solarization and the organic fertilizers significantly affected plant height at $\mathrm{P} \leq 0.01$, while the plant residue showed no significant effects on canola plant height, also there are no significant differences were detected between different plant residues, and also in interactions between different treatments (table $1)$.

\section{Flowering date:}

Analysis of variance (table 1) show significant differences between solarization treatments and also the amended organic fertilizers on flowering date of canola plants, but no significant differences were detected between different plant residues, and also in interactions between treatments on flowering date of the plant.

Table (1). Analysis of variance for plant height $(\mathrm{cm})$ and flowering date (day) of canola under the effects of solarization, plant residue, organic fertilizers and their interactions during 2015/2016 and 2016/2017 seasons.

\begin{tabular}{|c|c|c|c|c|c|}
\hline \multirow[t]{2}{*}{ Source of Variation } & \multirow[t]{2}{*}{ DF } & \multicolumn{2}{|c|}{ Plant height (cm) } & \multicolumn{2}{|c|}{ flowering date (day) } \\
\hline & & $2015 / 2016$ & $2016 / 2017$ & $2015 / 2016$ & $2016 / 2017$ \\
\hline Replication & 3 & NS & NS & NS & NS \\
\hline Solarization A & 3 & $4740.82 * *$ & $4894.8^{* *}$ & $5401.87 * *$ & $8641.4 * *$ \\
\hline error & 9 & 196.35 & 100.47 & 26.35 & 28.54 \\
\hline Plant residue $\mathrm{B}$ & 1 & NS & NS & NS & NS \\
\hline $\mathrm{A}^{*} \mathrm{~B}$ & 3 & NS & NS & NS & NS \\
\hline Error & 12 & & & & \\
\hline Organic fertilizer $\mathrm{C}$ & 2 & $2127.13 * *$ & $789.56^{* *}$ & $195.96^{* *}$ & $246.79 * *$ \\
\hline $\mathrm{A}^{*} \mathrm{C}$ & 6 & NS & NS & NS & NS \\
\hline $\mathrm{B} * \mathrm{C}$ & 2 & NS & NS & NS & NS \\
\hline $\mathrm{A} * \mathrm{~B} * \mathrm{C}$ & 6 & NS & NS & NS & NS \\
\hline Error & 48 & & & & \\
\hline
\end{tabular}

NS: Not significant at $\mathrm{P} \leq 0.05$

: **significant at $\mathrm{P} \leq 0.01$

\section{Number of branches per plant}

Data of table (2) of analysis of variance of branch numbers per plant under the effects of the different treatments showed significance effects of solarization and the organic fertilizers at $\mathrm{P} \leq 0.01$ on number of branches/plant. No significant effects were shown between plant residue and also in interaction between treatments.
Number of fruits per plant:

Analysis of variance (Table 2) results illustrated significant differences between solarization and organic fertilizers treatments on number of fruits/plant at $\mathrm{P} \leq 0.01$, with no significant effect of plant residue and interaction between treatments on fruits/plant in both seasons. 
Table (2). Analysis of variance of number of branches/plant and number of fruits/plant of canola under the effect of type of solarization, plant residue, organic fertilizers and their interactions during 2015/2016 and 2016/2017seasons.

\begin{tabular}{|c|c|c|c|c|c|}
\hline \multirow[t]{2}{*}{ Source of Variation } & \multirow[t]{2}{*}{ DF } & \multicolumn{2}{|c|}{ Number of branches/plant } & \multicolumn{2}{|c|}{ Number of fruits/plant } \\
\hline & & $2015 / 2016$ & $2016 / 2017$ & $2015 / 2016$ & $2016 / 2017$ \\
\hline Replication & 3 & NS & NS & NS & NS \\
\hline Solarization A & 3 & $62.15^{* *}$ & $52.24 * *$ & $22711.87 * *$ & $24422.4 * *$ \\
\hline error & 9 & 196.35 & 100.47 & 26.35 & 28.54 \\
\hline Plant residue B & 1 & NS & NS & NS & NS \\
\hline $\mathrm{A} * \mathrm{~B}$ & 3 & NS & NS & NS & NS \\
\hline Error & 12 & & & & \\
\hline Organic fertilizer $\mathrm{C}$ & 2 & $18.34 * *$ & $35.48^{* *}$ & $10127.2^{* *}$ & $48976.7 * *$ \\
\hline $\mathrm{A} * \mathrm{C}$ & 6 & NS & NS & NS & NS \\
\hline $\mathrm{B} * \mathrm{C}$ & 2 & NS & NS & NS & NS \\
\hline$A * B * C$ & 6 & NS & NS & NS & NS \\
\hline Error & 48 & & & & \\
\hline
\end{tabular}

NS: Not significant at $\mathrm{P} \leq 0.05 * *$ : significant at $\mathrm{P} \leq 0.01$

\section{Comparison of the means}

\section{Plant height:}

Effect of soil solarization:

As shown in Table (3) mulching Covering the soil with 100 $\mu$ polyethylene thickness gave the tallest canola plants 153.20 $\mathrm{cm}$ and 145.62, in both seasons respectively compared with other thicknesses and control, and plant height decrease gradually with increase in polyethylene thickness gave. All polyethylene thickness treatments significantly dominated the control giving higher plant heights in both seasons. Effect of solarization in giving taller canola plants than uncovered soil may be due to the decrease in weed density and biomass under effect of soil covering thus increase plant height as was also reported by (Habeebrrahman and Hosmani , 1996; Biradar and Hosamani, 1997; Sudha et al., 1997; Arora and Yaduraju, 1998; Chase et al., 1998; Defilippi et al., 1998; Patel and Patel, 1998. Campiglia et al., 1998; Sunbol and AlSolaimani 1999 a, b; Al-Solaimani and sunbol 2000 a,b.). And also might be due to increase in concentration of nutrients released in the solarized soil compared to unsolarized soil (Zayed et al., 2013).

\section{Effect of Plant residue:}

Means plant height range between $129.9-136.5 \mathrm{~cm}$ in the 2 seasons with no significant differences between cabbage and canola plant residue Table (3).

\section{Effect of organic fertilizers:}

Data of Table (3) showed that chicken manure organic fertilizer produced significantly the tallest plant in both seasons, where the plant height were $144.48 \mathrm{~cm}$ and 135.68 $\mathrm{cm}$, respectively, followed by sheep manure and cow manure with significant differences. The obtained results might be due to the acidic reaction and high $\mathrm{N}$ content of the chicken manure which is reflected in enhancing cell enlargement and division thus increasing plant height compared to the other organic fertilizers.

\section{Flowering date:}

Effect of soil solarization:

Covering soil with polyethylene $100 \mu$ in thickness significantly delayed canola plant flowering date in both seasons compared with the other treatments. By increasing polyethylene thickness from 100 to 250 and $500 \mu$ flowering dates were delayed by around 21 and 8 days compared to control (Table 3).

\section{Effect of Plant residue:}

No significant differences between cabbage and canola plant residue treatments on flowering date of canola plant in both seasons (Table 3), but flowering date delayed around 15 days in the 2 nd season due to effects of environment conditions.

\section{Effect of organic fertilizers}

Flowering date (table 3) was the longest under chicken manure fertilization in both seasons with means of 59.66 and 75.02 days respectively compared to cow and sheep manure. Cow manure produced the shortest time to flowering with means of 54.72 and 68.43 days in the 2 seasons respectively. These results might be due to the differences between the 3 manures in their nutrients and $\mathrm{pH}$ as suggested by (Hemmat et al., 2010 b; Marzouk and Kassem, 2011).

Table (3). Means of canola plant height (cm) and flowering date (day) under the effects of solarization, plant residue and organic fertilizer during 2015/2016 and 2016/2017 seasons.

\begin{tabular}{|c|r|r|r|r|}
\hline \multirow{2}{*}{ Treatments } & \multicolumn{2}{|c|}{ Plant height $(\mathbf{c m})$} & \multicolumn{2}{c|}{ Flowering date (day) } \\
\cline { 2 - 5 } & $\mathbf{2 0 1 5 / 2 0 1 6}$ & $\mathbf{2 0 1 6 / 2 0 1 7}$ & $\mathbf{2 0 1 5 / 2 0 1 6}$ & $\mathbf{2 0 1 6} / \mathbf{2 0 1 7}$ \\
\hline \multicolumn{5}{|c|}{ Type of solarization (polyethylene thickness) $\mu$} \\
\hline $100 \mu$ & $153.2 \mathrm{a}$ & $14.6 \mathrm{a}$ & $75.35 \mathrm{a}$ & $94.2 \mathrm{a}$ \\
\hline $250 \mu$ & $139.7 \mathrm{~b}$ & $138 \mathrm{~b}$ & $62.45 \mathrm{~b}$ & $78.5 \mathrm{~b}$ \\
\hline $500 \mu$ & $133 \mathrm{c}$ & $124.6 \mathrm{c}$ & $49.4 \mathrm{c}$ & $63.5 \mathrm{c}$ \\
\hline Control & $119.3 \mathrm{~d}$ & $113.3 \mathrm{~d}$ & $41.12 \mathrm{~d}$ & $50.4 \mathrm{~d}$ \\
\hline
\end{tabular}




\begin{tabular}{|c|c|c|c|c|}
\hline \multicolumn{5}{|l|}{ Plant residues } \\
\hline Cabbage & $136.4 \mathrm{a}$ & $130.9 \mathrm{a}$ & $57.49 \mathrm{a}$ & $72.4 \mathrm{a}$ \\
\hline Canola & $136.5 \mathrm{a}$ & $129.9 \mathrm{a}$ & $56.8 \mathrm{a}$ & $70.9 \mathrm{a}$ \\
\hline \multicolumn{5}{|l|}{ Organic fertilizers } \\
\hline Chicken manure+sludge & $144.4 \mathrm{a}$ & $135.6 \mathrm{a}$ & $59.6 \mathrm{a}$ & $75.2 \mathrm{a}$ \\
\hline Cow manure+sludge & $136.7 \mathrm{~b}$ & $129.8 \mathrm{~b}$ & $56.9 \mathrm{~b}$ & $71.6 \mathrm{~b}$ \\
\hline Sheep manure+ sludge & $128.1 \mathrm{c}$ & $125.8 \mathrm{c}$ & $54.7 \mathrm{c}$ & $68.4 \mathrm{c}$ \\
\hline
\end{tabular}

Number of branches per plant:

Effect of soil solarization:

As shown in Table (4) the $100 \mu$ polyethylene thickness produced the highest number of branches/plant in both seasons giving 22.96 and 21.28 , respectively, followed by $250 \mu$ and $500 \mu$ with significant differences between them and the lowest number of branches/plant was in control treatment 8.07 and 6.72 respectively in the 2 seasons. Soil solarization might have enhanced and increased the concentration of nutrients in the soil as was indicated by Stapleon et al., 1985; Adetunji, 1994; Arora,1998 ; Arora and Yaduraju, 1998; Al-Solaimani et al., 2006, and also due to decrease in weed, fungi and bacteria populations in the soil thus benefiting and increasing plants growth, and this is incorporated with the results of (Habeebrrahman and Hosmani , 1996; Biradar and Hosamani, 1997; Sudha et al., 1997; Arora and Yaduraju, 1998; Campiglia et al., 1998; Chase et al., 1998; Defilippi et al., 1998; Patel and Patel, 1998 ; Simmons et al., 2013).

Effect of Plant residue:

Number of branches/plant was not significantly cabbage and canola Plant residue treatments in both seasons. Branches number /plant reached 9 and 8 in the 1 st and 2nd seasons, respectively, (Table 4).

Effect of organic fertilizers:

The means (Table 4) revealed that chicken manure produced significantly the highest number of branches per plant in both seasons, with 21.72 and 9.23 branches, respectively compared to cow and sheep manure which attained the lowest no. of branches/plant 9.10 and 8.17 in the 1 st and 2nd seasons, respectively

Number of fruits per plant:

Effect of soil solarization:

$100 \mu$ polyethylene thickness mulching produced the highest number of fruits per plant in both seasons 623.64 and 606.4 followed in a gradual decrease by $360 \mu, 500 \mu$ and the lowest was the control treatment with only 397.8 and 372.39 flowers / plant in the 1st and 2nd seasons. No significant differences were showed between the $360 \mu$ and $500 \mu$ in each seaso (table 4).

Effect of Plant residue:

No significant differences in no. fruits/plant between cabbage and canola Plant residue treatments in both seasons (Table 4). No. fruits/plant ranged from 507.91 - 489.62 under cabbage residue in the 2 seasons respectively but under the canola residue ranged from 482.42 to 471.03 in the 1 st and 2 nd seasons, respectively.

Effect of organic fertilizers:

The highest means of no. fruits/plants were under the effect of chicken manure in both seasons (550.66 and 520.18, respectively), followed by sheep manure (496.89 and 478.81 in the 1 st and 2nd seasons, respectively) while the lowest no. fruits/plants were produced under the cow manure and ranged between 437.94 and 441.98 in both seasons, , respectively.

Table (4), Means of no. of branches/plant and no. of fruits/plant of canola under the effects of solarization, plant residue and organic fertilizer during 2015/2016 and 2016/2017 seasons.

\begin{tabular}{|c|c|c|c|c|}
\hline \multirow[t]{2}{*}{ Treatments } & \multicolumn{2}{|c|}{ No. of branches/plant } & \multicolumn{2}{|c|}{ No. of fruits/plant } \\
\hline & $2015 / 2016$ & $2016 / 2017$ & 2015/2016 & 2016/2017 \\
\hline \multicolumn{5}{|c|}{ Type of solarization (polyethylene thickness) $\mu$} \\
\hline $100 \mu$ & $11.95 \mathrm{a}$ & $10.18 \mathrm{a}$ & $623.6 \mathrm{a}$ & $606.4 \mathrm{a}$ \\
\hline $250 \mu$ & $9.96 \mathrm{~b}$ & $7.93 \mathrm{~b}$ & $510.6 \mathrm{~b}$ & $508.7 \mathrm{~b}$ \\
\hline $500 \mu$ & $9.45 \mathrm{~b}$ & $7.58 \mathrm{~b}$ & $448.5 \mathrm{ab}$ & $433.7 \mathrm{c}$ \\
\hline Control & $8.07 \mathrm{c}$ & $7.73 \mathrm{c}$ & $397.8 \mathrm{c}$ & $372.3 \mathrm{~d}$ \\
\hline \multicolumn{5}{|l|}{ Plant residues } \\
\hline Cabbage & $9.98 \mathrm{a}$ & $8.15 \mathrm{a}$ & $507.9 \mathrm{a}$ & $489.6 \mathrm{a}$ \\
\hline Canola & $9.74 \mathrm{a}$ & $8.0 \mathrm{a}$ & $482.1 \mathrm{a}$ & $471.0 \mathrm{a}$ \\
\hline \multicolumn{5}{|l|}{ Organic fertilizers } \\
\hline Chicken manure+sludge & $10,6 \mathrm{a}$ & $9.1 \mathrm{a}$ & $550.6 \mathrm{a}$ & $520.1 \mathrm{a}$ \\
\hline Cow manure+sludge & $9.87 \mathrm{~b}$ & $7.1 \mathrm{~b}$ & $496.8 \mathrm{~b}$ & $478.8 \mathrm{~b}$ \\
\hline Sheep manure+ sludge & $9.1 \mathrm{c}$ & $8.1 \mathrm{c}$ & $437.9 \mathrm{c}$ & $441.9 \mathrm{c}$ \\
\hline
\end{tabular}

Means followed by the same letter(s) are not significantly different according to LSD at $\mathrm{P} \leq 0.05$ 
Seed weight per plant:

\section{Effect of soil solarization:}

The obtained results (Table 5) the $100 \mu$ polyethylene thickness produced significantly the highest seed weight / plant in both seasons, (41.73 $\mathrm{g}$ and $38.2 \mathrm{~g}$ in the 1st and 2nd seasons, respectively) compared to the other polyethylene thickness treatments. The lowest seed weight/plant was under no solarization (control) with $24.20 \mathrm{~g}$ and $21.97 \mathrm{~g} / \mathrm{plant}$ in the 1 st and 2 nd seasons, respectively.

ffect of Plant residue:

No significant differences between cabbage and canola plant residue treatments both seasons on canola seed weight/plant. Seed weight/plant was $27 \mathrm{~g} /$ plant in the 1 st season and 25 $\mathrm{g} /$ plant in the 2 nd season as shown in (table 5).

Effect of organic fertilizers:

Chicken manure produced significantly the highest seed weight/plant in both seasons, with $39.95 \mathrm{~g}$ and $37.32 \mathrm{~g}$, respectively followed by the sheep then cow manures. No significant differences between sheep and cow manure treatments in the 1 st season. The lowest seed weight/plant was $22.56 \mathrm{~g}$ under cow manure application in the 2 nd season (table4). The obtained results of the domination of the $100 \mu$ polyethylene thickness and the chicken manure over the other polyethylene or control treatments and the other organic fertilizers for seed weight/plant production may be due to the higher temperature under the $100 \mu$ polyethylene solarization which act on reduction of weed and soil pests populations more than the other thickness, organic manure treatments and control. And the domination of chicken manure in giving the highest seed weight/plant agrees with results obtained by (Klein et al., 2012, Sunboul and Al-Solaimani, 1999, and Simmons et al., 2013, 2014, Smith, 1997, Hemmat et al., 2010 a, Mauromicale et al., 2011 and Hamooh, 2014) who acknowledged that chicken manure had less $\mathrm{PH}$ and more nutrients than the other organic fertilizers.

Seed Quality

Seed Protein content:

Effect of soil solarization:

Significant differences were shown between the 4 soil solarization treatments in both seasons. The highest seed protein content were $30.63 \%$ and $31.08 \%$ under the $100 \mu$ polyethelen in the 1 st and 2 nd seasons, respectively compared to the other soil covering treatments. No significant differences between Protein (\%) under the $500 \mu$ and control in the 2 nd season. The lowest seed protein content was $23.18 \%$ under no solarization in the 2 nd season (Table 5).

\section{Effect of Plant residue:}

There was no significant difference between cabbage and canola plant residue treatments in both seasons (Table 5). The protein (\%) ranged from $26.90 \%$ to $26.19 \%$.

Effect of organic fertilizers:

The results in table (5) showed significant differences between the 3 different organic manures in both seasons, with chicken manure giving the highest seed protein percentage ranged between $28.46 \%$ and $32.15 \%$ in the 2 seasons, respectively. The lowest protein content (\%) was $21.23 \%$ under sheep manure treatment in the 2 nd season.

Seed Oil content:

Effect of soil solarization:

$100 \mu$ polyethylene thickness mulching produced plants with the highest oil (\%) in both seasons, with means of $34.48 \%$ and $33.11 \%$, respectively (table 5 with no significant differences between oil content under the 3 polyethylene thickness treatments, and also, between the control and $250 \mu$ and $500 \mu$ polyethylene thickness in oil content in both seasons.

\section{Effect of Plant residue:}

No significant differences in oil (\%) between the cabbage and canola Plant residue treatments in both seasons (Table 5). Oil content (\%) ranged between $31.62 \%$ to $30.64 \%$ under cabbage residue in the 1 st season and the 2 nd season, respectively.

\section{Effect of organic fertilizers:}

The highest oil (\%) in 1st and 2nd seasons (35.08\% and $33.92 \%$, respectively) were obtained by fertilizing with chicken manure. The lowest oil (\%) were $27.75 \%$ and $28.09 \%$ obtained from the seeds of canola plants grown in soil fertilized with cow manure in the 1 st and 2 nd seasons, respectively as shown in Table (5).

Table (5). Means of canola seed protein content (\%) and oil content (\%) under the effects solarization, plant residue and organic fertilizer during 2015/2016 and 2016/2017 seasons

\begin{tabular}{|c|c|c|c|c|c|c|}
\hline \multirow[t]{2}{*}{ Treatments } & \multicolumn{2}{|c|}{ Protein content $(\%)$} & \multicolumn{2}{|c|}{ Oil content $(\%)$} & \multicolumn{2}{|c|}{ Seed weight/plant } \\
\hline & $2015 / 2016$ & 2016/2017 & $2015 / 2016$ & 2016/2017 & $2015 / 2016$ & 2016/2017 \\
\hline \multicolumn{7}{|c|}{ Type of solarization (polyethylene thickness) $\mu$} \\
\hline $100 \mu$ & $30.6 \mathrm{a}$ & $31.0 \mathrm{a}$ & $34.4 \mathrm{a}$ & $33.1 \mathrm{a}$ & $30.62 \mathrm{a}$ & $28.12 \mathrm{a}$ \\
\hline $250 \mu$ & $27.6 \mathrm{~b}$ & $27.3 \mathrm{~b}$ & $34.2 \mathrm{ab}$ & $31.2 \mathrm{ab}$ & $29.73 \mathrm{a}$ & $26.23 \mathrm{ab}$ \\
\hline $500 \mu$ & $25.3 \mathrm{c}$ & $23.9 \mathrm{c}$ & $31.1 \mathrm{ab}$ & $30.1 \mathrm{ab}$ & $25.17 \mathrm{~b}$ & $23.31 \mathrm{bc}$ \\
\hline Control & $23.7 \mathrm{~d}$ & $23.2 \mathrm{~d}$ & $28.9 \mathrm{~b}$ & $28.6 \mathrm{~b}$ & $24.2 \mathrm{~b}$ & $21.97 \mathrm{c}$ \\
\hline \multicolumn{7}{|l|}{ Plant residue } \\
\hline Cabbage & $26.6 \mathrm{a}$ & $26.6 \mathrm{a}$ & $31.6 \mathrm{a}$ & $30.6 \mathrm{a}$ & $27.31 \mathrm{a}$ & $25.78 \mathrm{a}$ \\
\hline Canola & $26.9 \mathrm{a}$ & $26.1 \mathrm{a}$ & $31.2 \mathrm{a}$ & $30.9 \mathrm{a}$ & $27.55 \mathrm{a}$ & $24.03 \mathrm{a}$ \\
\hline \multicolumn{7}{|l|}{ Organic fertilizers } \\
\hline Chicken manure+sludge & $28.4 \mathrm{a}$ & $32.1 \mathrm{a}$ & $35 \mathrm{a}$ & $33.9 \mathrm{a}$ & $29.94 \mathrm{a}$ & $27.21 \mathrm{a}$ \\
\hline Cow manure+sludge & $25.4 \mathrm{~b}$ & $25.8 \mathrm{~b}$ & $31.5 \mathrm{~b}$ & $303 \mathrm{~b}$ & $26.68 \mathrm{~b}$ & $24.95 \mathrm{~b}$ \\
\hline Sheep manure+ sludge & $25.4 \mathrm{~b}$ & $21.2 \mathrm{c}$ & $27.7 \mathrm{c}$ & $28.0 \mathrm{c}$ & $25.67 \mathrm{c}$ & $22.56 \mathrm{c}$ \\
\hline
\end{tabular}


The domination of $100 \mu$ polyethylene treatment may be due to allowance of more light reaching the plants, initiation of more plant nutrients in the soil and eradication of weed growth at magnitudes more than that of the other thicknesses. On other hand the superiority of chicken manure compared to the other organic manures in all these studied parameters is due to the high nutritional values of chicken manure. Chicken manure is the feces of chickens used as an organic fertilizer, especially for soil low in nitrogen as said by, and it has the highest amount of nitrogen, phosphorus, and potassium (Telkamp, 2015). Amanullah et al. 2010 pointed out that chicken manure in addition to high content of $\mathrm{N}, \mathrm{P}, \mathrm{K}$, it also contains micro-nutrients at considerable amount. And thus it enhances the physical and chemical properties of the soil, increases the moisture holding capacity of the soil and improves lateral water movement, and improves soil retention and uptake of plant nutrients. All these are favorable conditions for good crop production.

\section{CONCLUSION}

Soil solarization by covering soil with different transparent polyethylene differ in thicknesses amended or not amended with cabbage and canola residues, and with or without organic manures (chicken manure + sludge, cow manure + sludge, sheep manure + sludge) significantly enhanced and increased growth parameters of canola plant and its seed protein and oil contents compared to control treatments. These treatments significantly increased canola plant height reduced canola plant flowering date, increased number of branches per plant, number of fruits per plant, seed weight per plant and also improved and enhanced canola seed protein and oil content. Soil solarization with transparent polyethylene $100 \mu$ thickness, and amending with chicken manure is recommended in growing canola plants.

\section{REFERENCES}

[1] A.O.A.C. (2000).Association of Official agricultural Chemists : Official and Tentative Methods.

[2] Addabbo, T.; Miccolis, V.; Basile, M.; Candido, V. (2018). Soil Solarization and Sustainable Agriculture. ook Sociology, Organic Farming, Climate Change and Soil Science (pp.217274)

[3] Adetunji, I. A. (1994). Response of onion to soil solarization and organic mulching in semi-arid tropics. Scientia Horticulturae, 60: 161 - 166 .

[4] Akhtar M., Malik A. (2000) Roles of organic soil amendments and soil organisms in the biological control of plant-parasitic nematodes: a review, Bioresour. Technol. 74, 35-47.

[5] Al-Solaimani, S. G. and Sunboul Y. H., (2000 a). Effect of Soil Solarization and Chicken Manure Addition on Corn Yield and Nitrogen Uptake under Arid Zone Conditions. Mansoura University Jou. Of Agr. Sci, 25 (1): 70-82

[6] Al-Solaimani, S. G., Sunbol Y. H., Al-Fasi F. A. and Bernawi, M. B. (2006). Effect of Soil Solarization and Animal Manure Addition on some Soil chemichal properties. African Studies Review, 28: 45-64

[7] Amanullah, M.M., E. Somasundaram, A. Alagesan and K. Vaiyapuri, 2007. Influence of fertilizer and organic manures on the yield and quality of cassava (Manihot esculenta Crantz.). Int. J. agric. Sci., 3: 181-186.

[8] Arora, A. (1998). Soil solarization: Effects on soil moisture, soil temperature and chemical properties of the soil. Crop Research Hisar, 16 (1): $41-49$.
[9] Arora, A. and Yaduraju, N. T. (1998). High temperature effects on germination and viability of weed seeds in soil. Journal of Agronomy and Crop Science, 181 (1): 35 - 43.

[10] Assaf T.A., Hameed K.M., Turk M.A., Al-Tawaha A.M. (2006) Effect of soil amendment with olive mill by-products under soil solarization on growth and productivity of faba bean and their symbiosis with mycorrhizal fungi, World J. Agric. Sci. 2, $21-$ 28.

[11] Budhar, M.N., SP. Palaniappan and A. Rangasamy, 1991. Effect of farm wastes and green manures on lowland rice. Indian $\mathrm{J}$. Agron., 36: 251-252.

[12] Biradar, I. B. and Hosmani, M. M. (1997). Effect of soil solarization on weed control and its after effects on growth and yield of groundnuts (Arachis hypogaea L.). Karnataka Journal of Agricultural Sciences, 10 (4): 966 - 970

[13] Campiglia, E., Temperini, O., Mancinelli, R., Marucci, A. and Saccardo, F. (1998). Soil solarization in the mediterranian environment: Effect on weed control and yield of cos lettuce (Lactuca sativa L., var longifolioa lam). Italus-Hortus 5 (3): 36 -42 .

[14] Chase, C. A., Sinclair, T. R., Chilling, D. G., Gilreath, J. P. and Locascio, S. J. (1998). Light effects on rhizome morpgogenesis in nutsedges (Cyperus spp.): Implications for control by soil solarization. Weed Science, 46 (5): 575 - 580.

[15] Chen Y., Katan J., Gamliel A., Aviad T., Schnitzer M. (2000) Involvement of soluble organic matter in increased plant growth in solarized soil, Biol. Fertil. Soils 32, 28-34.

[16] Defilippi, B., Montealegri, J. and Diaz, V. (1998). Control of weeds by soil solarization and methyl bromide in Sanpedro, metropolitan region, Chile. Agro-Sur, 26 (1): 26 - 35.

[17] Gamliel A., Austerweil M., Kritzman G. (2000) Non-chemica approach to soilborne pest management - organic amendments, Crop Prot. 19, 847-853.

[18] Gelsomino A., Cacco G. (2006) Compositional shifts of bacterial groups in a solarized and amended soil as determined by denaturing gradient gel electrophoresis, Soil Biol. Biochem. $38,91-102$

[19] Habeebrrahman, P. V. and Hosmani, M. M. (1996). Effect of soil solsrization in summer on weed growth and yield of succeeding rainy-season sorghum (sorghum biocolor). Indian Journal of Agronomy, 41(1): 54 - 57.

[20] Hamooh, B., (2014). Soil Solarization Duration and Animal Manure Effects on Soil Nutrients, Fungi, Weed and Yield of Eggplant (Solanum melongena L.) \& Cabbage (Brassica oleracea). International Journal of Engineering Research \& Technology, 3: 1- 2278-0181.

[21] Hemmat, A., Aghilinategh, N., Rezainejad, Y. and Sadeghi, M., (2010a). Long-term impacts of municipal solid waste compost, sewage sludge and farmyard manure application on organic carbon, bulk density and consistency limits of a calcareous soil in central Iran, Soil \& Tillage Research, Vol. 108. Elsevier Science Ltd, Isfahan, Iran, pp 43-50

[22] Hemmat, A., Aghilinategh, N., Sadeghi, M., (2010b). Shear strength of repacked remoulded samples of a calcareous soil as affected by long-term incorporation of three organic manures in central Iran, biosystems engineering, Vol. 107. Elsevier Science Ltd, Isfahan, Iran, pp 25 1-2 61

[23] Katan J (2000) Physical and cultural methods for the management of soil-borne pathogens. Crop Prot 19:725-731.

[24] Katan J, Grinstein A, Greenberger A, Yarden O, DeVay JE (1987) The first decade (1976-1986)

[25] Klein E., Katan J. and Gamliel A. (2012) Soil suppressiveness to Meloidogyne javanica as induced by organic amendments and solarization in greenhouse crops. Crop Protection 39 $26 \mathrm{e} 32$

[26] Marzouk H. A., Kassem H. A., (2011). Improving fruit quality, nutritional value and yield of Zaghloul dates by the application of organic and/or mineral fertilizers, Scientia Horticulturae Vol 127. Elsevier Science Ltd, Alexandria, Egypt, pp 249-254

[27] Mauromicale, G. , Longo, A. M. G., Monaco, A. L. (2011). The effect of organic supplementation of solarized soil on the quality of tomato fruit, Scientia Horticulturae, 129: 189-196.

[28] ment. In: Reuveni R (ed) Novel approaches to integrated pest management. Lewis, Boca 
[29] of soil solarization (solar heating): a chronological bibliography. Phytoparasitica 15:229-255

[30] Patel, B. K. and Patel, H. R. (1998). Effect of soil solarization, rabbing, nematocides and green manuring on groth and development of bidi tobacco seedlings, root 888 knot disease, weeds and phytonematodes in nursery. Indian Journal of Nematology 28 (1): $15-21$.

[31] Saleha, A., 1992. Studies on the effect of organic V/S inorganic form of nitrogen on the quality of Okra. J. Maharashtra Agric. Univ., 17: 133-134.

[32] Zamil, S.S., Q.F. Quadir, D.M.A.H. Chowdhury and A. Al Wahid, 2004. Effects of different animal manures on yield quality and nutrient uptake by mustard cv. Agrani. BRAC Univ. J., 1: 59-66.

[33] Simmons, C. W., Claypool, J. T., Marshall, M. N., Jabusch, L. k., Reddy, A. P., Simmons, B. A., Singer, S. W., Stapleton, J. J. and VanderGheynst, J. S. (2014). Characterization of bacterial communities in solarized soil amendedwith lignocellulosic organic matter. Applied Soil Ecology, 73: 97- 104

[34] Simmons, C. W., Guo, H., Claypool, J. T., Marshall, M. N., Perano, K. M., Stapleton, J. J. and VanderGheynst, J. S. (2013). Managing compost stability and amendment to soil to enhance soil heating during soil solarization. Waste Management, 33: 1090-1096.

[35] Stapleton JJ (2000) Soil solarization in various agricultural production systems. Crop Pro. 19:837-841. doi:

[36] Stapleton JJ, DeVay JE (1995) Soil solarization: a natural mechanism of integrated pest manage- Biological and Cultural Tests for Control of Plant Diseases, Vol. 12. APS Press, St. Paul, pp. 1-6.
[37] Stapleton, J.J., (1985). Solarization: An implementable alternative for soil disinfestation. In: Canaday, C. (Ed.) Biological and Cultural Tests for Control of Plant Diseases, Vol. 12. APS Press, St. Paul, pp. 1-6.

[38] Sudha, T., Nanjappa, H. V., Ramachandrappa. B. K. Mudalagiriyappa, P. and Mallikarjuna, G. B. (1997). Weed control in chili and capsicum nursery by soil solarization. Karnataka Journal of Agricultural Sciences, 10 (4): 1177 - 1180.

[39] Sunboul, Y. H. and Al-Solaimani S. G. (1999 a). Soil Chemical Composition and Fungal Populations as Affected by a Combination of Soil Solarization Chicken Manure Amendment., Journal of Zagazig University (Banha Branch), Annals of Agricultural Science Moshtohor. 37(4):2655-2666.

[40] Sunboul, Y. H. and Al-Solaimani S. G., (1999 b). Weed Growth as Affected by Combination of Soil Solarization and Chicken Manure Amendment under Corn Plantation, Journal of Zagazig University (Banha Branch). Annals of Agricultural Science Moshtohor. 37 (4) : 2643-2654.

[41] Telkamp, Mick. The Straight Poop On Using Chicken Manure as Fertilizer. Retrieved 16 February 2015.

[42] Thuriès L., Larreé-Larrouy M.C., Feller C. (2000) Influence of organic fertilization and solarization in a greenhouse on particlesize fraction of a Mediterranean sandy soil, Biol. Fertil. Soils 32, 449-457.

[43] Zayed M.S., Hassanein, M. K., Esa, N. H. and Abdallah, M. M. (2013). Productivity of pepper crop (Capsicum annuum L.) as affected by organic fertilizer, soil solarization, and endomycorrhizae. Annals of Agricultural Science, 58(2): 131137. 